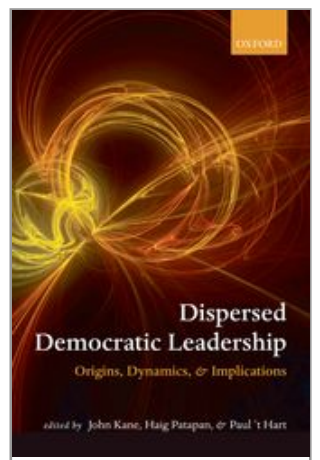

Dispersed Democratic Leadership: Origins, Dynamics, and Implications

John Kane, Haig Patapan, and Paul 't Hart

Print publication date: 2009

Print ISBN-13: 9780199562992

Published to Oxford Scholarship Online: October 2011

DOI: 10.1093/acprof:oso/9780199562992.001.0001

\title{
Leadership by the Famous: Celebrity as Political Capital
}

\author{
Paul 't Hart \\ Karen Tindall
}

DOI:10.1093/acprof:oso/9780199562992.003.0014

\begin{abstract}
Keywords
Many of us care about refugees and displaced children. Tens of thousands of us spend considerable amounts of time and money improving their situation. But few of us have been as effective in drawing attention to these issues and keeping them on the agenda of political elites and institutions around the world as celebrities such as Angelina Jolie have been. Star power defies conventional accounts of democratic leadership. It epitomizes the notion of leadership dispersal, although not one that is the product of institutional design let alone constitutional foresight. It rests upon personal rather than institutional moral capital, that capital is derived from fame, dramaturgy, and personality marketing in the non-political sphere, rather than by democratic election, representation, and accountability.
\end{abstract}

Keywords: celebrity politics, celebrities, leadership, mobilization, democratic politics, democracy, elections, activism

'When a celebrity talks, people listen; there is no better messenger.'

(Ford and Goodale, cited in Cooper 2008: 114)

\section{Star power}

Many of us care about refugees and displaced children. ${ }^{1}$ Tens of thousands of us spend considerable amounts of time and money improving their situation. But few of us have been as effective in drawing attention to these issues and keeping 
them on the agenda of political elites and institutions around the world as celebrities such as Angelina Jolie. In the last six years she has evolved into a formidable agenda-setter, a tenacious lobbyist, and a grand benefactor. A regular fixture in the last few instalments of the Time 100 list of the year's most influential people, Angelina Jolie is no longer just an actress and a celebrity figure. She has come to be seen as a public leader.

In fact, she is a public leader because she is a valuable Hollywood commodity. She deftly uses her famous name, physique, and performative qualities to gain clout in the world beyond Hollywood and to advance the causes she has come to embrace ever since shooting a movie in Cambodia. Jolie understands that a celebrity is not just someone hounded by tabloid journalists but also 'an individual whose name has attention-getting, interest-riveting and profitgenerating value' (Rein, Kottler, and Stoller 1987: 15). She is by no means the first big-name humanitarian activist (cinema icon Audrey Hepburn is considered one of the pioneers of humanitarian activism in Hollywood), but Jolie has succeeded on a much larger scale than Hepburn ever contemplated. Jolie represents a paradigmatic example of 'star power' at work in the world of international politics (Cooper 2008: 32-5). She and other modern (p.256) day 'celebrity diplomats' such as Bono, Bob Geldof, and George Clooney know that 'celebrity sells' (Pringle 2004), but instead of (or as well as) selling watches, jewellery, fragrances, and cars they have chosen to 'sell' humanitarian causes and other political messages.

Star power defies conventional accounts of democratic leadership. It epitomizes the notion of leadership dispersal, although not one that is the product of institutional design let alone constitutional foresight. It rests upon personal rather than institutional moral capital. That capital is derived from fame, dramaturgy, and personality marketing in the non-political sphere, rather than by democratic election, representation, and accountability. It is a form of leadership by the well-known, not necessarily leadership by the well-qualified. In an era of boundless mass communication worldwide and 'entertainment culture' merging seamlessly with 'high culture' star power feels a lot more potent, connected and 'in tune' than electoral power. Unless of course, the two are aligned, with the one reinforcing the other and vice versa.

Many on both sides of the divide have seen this potential, and many have tried to exploit it. Rock stars rub shoulders with presidents and bankers to eradicate poverty. Politicians keenly seek endorsements of talk show hosts to get (re-)elected. NGOs lobby musicians and football stars to become their public faces. A former politician teams up with film makers to produce an Oscarwinning documentary and helps stage the world's biggest rock concert to push for action on global warming. A pro wrestler and a bodybuilder-turned-actor both get themselves elected as state governors in the United States. A poet 
becomes prime minister of the largest democracy in the world. In Australia, a former news presenter unseats a four-term prime minister at the ballot box.

There is no dearth of opinions about celebrity leadership, perhaps because it is clearly an emergent phenomenon that straddles 'democracy's edges' (cf. Shapiro and Hacker-Cordon 1999). But among the clamour of opinions on offer, there is surprisingly little in the way of empirical analysis. Where, how, and why do the worlds of celebrity and politics merge to produce forms of celebrity political leadership? These elementary questions have been given almost no coverage in the celebrity literature, which is scattered across disciplines such as cultural studies, media and communications, sociology and social psychology, with political science contributions modest in number and scope. In the first part of this chapter we shall try to lay some much-needed groundwork for a comparative analysis of celebrity politics in established democracies. We present four different forms of celebrity politics, and then dissect them in greater detail. We look at their critical features, how they are situated within democratic institutions and practices, and identify the sources of their leadership potential. Throughout the chapter, we formulate empirical propositions purporting to identify the institutional, cultural, and situational conditions of their occurrence and impact. These propositions are strictly explorative; they intend however to stimulate and inspire the kind of systematic comparative (p.257) research that is presently lacking. In the final section, we assess the rise of celebrity politics as a form of dispersed leadership.

Celebrity and politics: how the twain meet We should not make the mistake of thinking that we are dealing with a (post) modern phenomenon here. People who have already gained fame in another sphere of life have always been looked at to play public leadership roles. Quite a few of them have actively sought public office, or have been encouraged to do so by power brokers. Every epoch and culture produces its own 'stars' or at least skews the distribution of stardom in particular ways (Braudy 1986). When, as in ancient Rome, societies depended on armies and/or conquest for their survival and prosperity, successful military leaders were likely to be key heroes and potential recruits into political leadership positions. And this has extended into modern times: the United States has repeatedly turned to generals whose credentials for political office were largely that they were famous 'warriors'. Among others, generals Harrison, Grant, Eisenhower ('I like Ike') and, for a while, MacArthur and Powell were courted by parties (often both major parties at the same time) to be their standard bearer, and in some cases ended up as president.

Yet there have long been alternative bases for celebrity. When societies value achievement in science and the arts, inventors, investigators, painters, sculptors, and composers become celebrities (although historically relatively few of them seem to have sought or achieved formal public leadership positions). 
When societies are oppressed, dignified dissidents become popular heroes, and, after liberation, almost irresistible candidates for executive office (Mandela and Havel). And when the culture and economy of societies are permeated by an allencompassing and increasingly global sports and entertainment industry, highprofile people within that industry - today's sports, television, movie, rock, pop and hip-hop 'stars' - are handed a golden opportunity structure for political advocacy and/or careerism.

It is therefore important to acknowledge the contextual and contingent nature of celebrity. Firstly, whilst one may usefully analyse celebrity in terms of individual stardom and the political opportunities and choices of the people involved, it remains necessary to understand this as a broader social phenomenon embedded in and indicative of industries, cultures, and regimes (Turner 2004). Secondly, regardless of the original source of fame, celebrity involvement in politics itself can take very different forms (Monaco 1978; Rojek 2001; Mukherjee 2004; Street 2004). Therefore no grand, one-size-fits-all interpretation is sufficient. It is necessary to drill down into the specific circumstances and problems of different manifestations of celebrity politics: the celebrity activist, the celebrity endorser, the celebrity politician, and the politician-turned-celebrity. Each has its own distinctive contingencies, challenges, and implications for political (p.258) 


\section{Table 14.1 Celebrity leadership: a comparative overview}

\begin{tabular}{|c|c|c|c|c|}
\hline & Celebrity advocate & Celebrity endorser & Celebrity politician & Politician-celebrity \\
\hline Foundations & $\begin{array}{l}\text { Issue-focused: agenda- } \\
\text { setting and/ or policy- } \\
\text { seeking behaviour by } \\
\text { high-visibility figures } \\
\text { from traditionally non- } \\
\text { political spheres } \\
\text { (entertainment, arts, } \\
\text { sports, civil society, } \\
\text { journalism, and science) }\end{array}$ & $\begin{array}{l}\text { Office-focused: high- } \\
\text { visibility figures from } \\
\text { traditionally non-political } \\
\text { spheres offering financial } \\
\text { and/or public support for } \\
\text { a political candidate and/ } \\
\text { or party }\end{array}$ & $\begin{array}{l}\text { Office-seeking: legislative } \\
\text { or executive offices } \\
\text { sought by high-visibility } \\
\text { figures from traditionally } \\
\text { non-political spheres }\end{array}$ & $\begin{array}{l}\text { Office-transforming: } \\
\text { office-holder whose } \\
\text { public behaviour, } \\
\text { purposeful association } \\
\text { with celebrities, and/or } \\
\text { private life alter his } \\
\text { public persona beyond } \\
\text { the traditional political } \\
\text { sphere into the celebrity } \\
\text { sphere Subtypes: P-C1: } \\
\text { active (by intent); P-C2: } \\
\text { passive (by accident/ } \\
\text { scandal) }\end{array}$ \\
\hline $\begin{array}{l}\text { Nature of leadership } \\
\text { exercised }\end{array}$ & $\begin{array}{l}\text { Political mobilization: } \\
\text { Watchdog Agenda-setter } \\
\text { Educator Energizer }\end{array}$ & $\begin{array}{l}\text { Electoral momentum- } \\
\text { building }\end{array}$ & $\begin{array}{l}\text { Achieving formal } \\
\text { legislative or executive } \\
\text { leadership positions }\end{array}$ & $\begin{array}{l}\text { Not applicable. (P-C1: } \\
\text { power consolidation or } \\
\text { expansion) (P-C2: political } \\
\text { survival) }\end{array}$ \\
\hline $\begin{array}{l}\text { Relation to institutional } \\
\text { politics }\end{array}$ & Informal; not embedded & $\begin{array}{l}\text { Informal; partially } \\
\text { embedded }\end{array}$ & Formal; embedded & Informal; embedded \\
\hline
\end{tabular}




\begin{tabular}{|c|c|c|c|c|}
\hline & Celebrity advocate & Celebrity endorser & Celebrity politician & Politician-celebrity \\
\hline & $\begin{array}{l}\text { System-confirming: } \\
\text { refocusing public and } \\
\text { political agendas; } \\
\text { supporting existing } \\
\text { NGOs/IGOs System- } \\
\text { eroding: vocal criticism of } \\
\text { incumbent elites and } \\
\text { institutions }\end{array}$ & $\begin{array}{l}\text { System-confirming: } \\
\text { mobilizing support for } \\
\text { candidates in electoral } \\
\text { contests }\end{array}$ & $\begin{array}{l}\text { System-confirming: } \\
\text { celebrity chooses the path } \\
\text { of conventional, electoral } \\
\text { politics to exercise } \\
\text { leadership }\end{array}$ & $\begin{array}{l}\text { System-expanding: P-C1 } \\
\text { seeks to widen his/her } \\
\text { (and his/her policies') } \\
\text { appeal by reaching } \\
\text { 'beyond politics' P-C2's } \\
\text { private life is propelled } \\
\text { into the public limelight, } \\
\text { and becomes a political } \\
\text { issue }\end{array}$ \\
\hline \multirow[t]{2}{*}{ Leadership capital } & 'Concentrated star power' & 'Selective star power' & 'Constrained star power' & 'Borrowed star power' \\
\hline & $\begin{array}{l}\text { Has easy access to (free) } \\
\text { publicity, is a known and } \\
\text { liked public figure. Enjoys } \\
\text { personal wealth and/or } \\
\text { easy access to funds as } \\
\text { well as advocacy } \\
\text { professionals. Few } \\
\text { constraints on ability to } \\
\text { pursue 'unorthodox', } \\
\text { 'direct', 'controversial' } \\
\text { advocacy methods in the } \\
\text { service of a cause. }\end{array}$ & $\begin{array}{l}\text { Has easy access to (free) } \\
\text { publicity, is a known and } \\
\text { liked public figure. Enjoys } \\
\text { personal wealth and easy } \\
\text { access to other high- } \\
\text { profile donors and/or } \\
\text { endorsers. }\end{array}$ & $\begin{array}{l}\text { Has easy access to (free) } \\
\text { publicity, is a known and } \\
\text { often liked public figure, } \\
\text { and not (yet) 'tainted' by } \\
\text { politics as usual. Enjoys } \\
\text { personal wealth and easy } \\
\text { access to high-profile } \\
\text { endorsers and donors Has } \\
\text { 'outsider' status, and can } \\
\text { draw on references to } \\
\text { 'former life' to garner } \\
\text { support and/or avoid } \\
\text { punishment for } \\
\text { unorthodox political } \\
\text { behaviour. }\end{array}$ & $\begin{array}{l}\text { P-C1 uses privileged } \\
\text { access to celebrity } \\
\text { circles/events that comes } \\
\text { with office holding, and is } \\
\text { in fact key target for } \\
\text { celebrity activists' } \\
\text { political lobbying } \\
\text { activities. The smell of } \\
\text { 'something big' in P-C2's } \\
\text { personal life attracts } \\
\text { entertainment, gossip, } \\
\text { tabloid journalism that } \\
\text { would otherwise not } \\
\text { cover politicians. }\end{array}$ \\
\hline
\end{tabular}


(p.259) leadership. Table 14.1 provides a thumbnail sketch of each of these types, and its political leadership potential. We tackle each in turn.

Celebrity activists and endorsers: leadership by mobilization

While most celebrities today associate themselves with one or several charities, some put in a much greater effort for their chosen cause and seek to display public leadership on selected issues and causes. Celebrity activists and endorsers possess the potential resources to have a significant impact in the political process. These resources (both intangible and material) allow them easier access to the many echelons of democratic society (the leaders, the policy makers, and the public). They have time and money that they can devote to a limited number of causes. They are not constrained, as politicians are, by the need to cater to various segments of voters and keep interest groups on side. The difference between the two types is to a large extent one of degree: the endorser offers money and moral support to causes and candidates; the activist actually organizes campaigns, lobbies power-holders and turns up in the field to publicize causes. For our purposes here, however, we can treat them as two sides of the same coin.

Celebrity endorsers and activists face the same constraints that have hindered effective action on their chosen causes in the past (bureaucracy, congress/ parliament, organized interests, and geopolitics). The difference between them and professional politicians lies in the methods celebrities may employ to bypass or overcome these constraints. Celebrities do not have institutional power, but do tend to have money, or easy access to it. They can use it to make large, publicity-generating donations. It also enables them to 'buy in' issue expertise that they themselves (initially) lack (e.g. economist Jeffrey Sachs working with Jolie and Bono). More importantly they can use their fame to orchestrate intense media coverage, evoke public emotion, and thus mobilize large numbers of people. Their ability to sell products to the public, which is keenly sought by many firms, can be used to sell public ideas and political campaigns. Their own activist writings (or those they endorse) can be turned into best-seller books (Cheadle and Prendergast's Not On Our Watch: The Mission to End Genocide in Darfur and Beyond; Jolie's Notes From My Travels), and they can not only produce but also effectively market humanitarian/political documentaries (Clooney's Darfur Now; Jolie's The Diary of Angelina Jolie and Dr Jeffrey Sachs in Africa; DiCaprio's 11th Hour) that would otherwise easily be overlooked.

\section{Persona: the importance of seeming earnest}

Celebrity endorsement and activism are exercises in leadership by mobilization. Speaking out on a cause or donating money to it are necessary but not sufficient conditions for effective leadership of this kind. Like all advocates they need to captivate and energize their target audiences (whether it is the (p.260) public or a political leader and his staff). In order to do so they need to be seen to 
'know their business' and 'to be in it for the right reasons' (for instance, not to polish their own image and brand or to revive flagging careers).

These claims are easier to make for some celebrities than for others. Is their persona associated with intelligence, seriousness, and social responsibility, or does it epitomize quite the opposite? It takes no Platonic elitist to argue that on the required brainpower alone celebrities such as former Spice Girl Gerri Halliwell or tabloid favourite Lady Sarah Ferguson were out of their league when taking on ill-fated UN ambassadorial roles on the world political stage (cf. Cooper 2008). And it does not take a cynic to discern the hand of spin doctors and image consultants in 'socialite' Paris Hilton's sudden (and short-lived) interest in the plight of African children following her brief prison sojourn. Clearly, there is a publicly perceived and politically consequential distinction between 'activist leadership' and 'jumping on the bandwagon' by celebrities spurred by their managers. Some are hailed as 'serious' and 'dedicated', others are dismissed as lightweights and opportunists.

Like all political actors, celebrity endorsers and activists need to negotiate the world of facts as well as that of appearances and image in their quest for the authority they need to be able to persuade and mobilize. The difference among celebrities in doing so is that some are famous because of evident merit (even in 'non-high brow' sectors such as sports) whereas others, well, only because they are well-known (cf. Boorstin 1961), in however fleeting a fashion. One would expect these different starting points to affect the political capital they enjoy when turning their attention to public causes. Some examples illustrate the point. The polished public persona of 1970s German soccer star Franz Beckenbauer required very little adjustment for him to become Salonfähig in German and global sports leadership roles. To elevate Mike Tyson to a similar sort of stature is surely impossible. Earnest, never too wild rock stars like Bono and Peter Gabriel who both had penned fame-generating political anthems (Sunday Bloody Sunday and Biko, respectively) early in their careers had impeccable celebrity activist credentials. For a Marilyn Manson (shock rocker), Michael Jackson ('Wacko Jacko'), or Britney Spears (compromised teen idol) to take the same route would not be impossible but would require a substantial and convincing 'image makeover'.

There is, however, an alternative interpretation. Perhaps power is simply in numbers and not so much in cultural capital. This is sometimes referred to as the difference between 'A-list' and 'minor' celebrities, depending on the pervasiveness of their fame. Brad Pitt and David Beckham are known in all corners of the world, whereas Peter Gabriel's or cyclist Lance Armstrong's fame is more limited to particular niches of fans but equally enduring among them. At the other extreme there are the 'celetoids' (Rojek 2001) whose fame is artificially created by the entertainment industry (reality TV 'stars' for example) and usually mainly local as well as short-lived. Consequently, the former should 
enjoy (p.261) a competitive advantage over the latter in the market of celebrity activism. ${ }^{2}$ Hence a first set of propositions can be offered:

Proposition 1: The more merit-based the source of a celebrity's initial fame, the more likely that this celebrity's charitable and political activities will be seen as significant and successful.

Proposition 2a: The higher the social prestige of the cultural sphere in which a celebrity gained fame, the more likely that this celebrity's charitable and political activities will be seen as significant and successful.

Proposition 2b: The broader (geographical, numerical) and wider (across social strata and cultural groups) a celebrity's fame, the more likely that this celebrity's charitable and political activities will be seen as significant and successful.

Proposition 2c: The more enduring a celebrity's fame, the more likely that this celebrity's charitable and political activities will be seen as significant and successful.

Tactics: Penetrating the public mind and the corridors of power.

As stated, in at least one respect, celebrity endorsers and activists come from behind when trying to lead: they cannot make a simple claim to represent 'the people', as any elected politician can. Although Street (2004) has rightly criticized the narrow notion of representation that lies behind such claims (see also Saward 2006), the argument continues to be raised. In fact, segments of the public seem to have become more critical of celebrity endorsement and activism for that reason: a September 2007 CBS/ New York Times News Poll showed that 49 per cent of Americans think celebrities should stay out of politics (up from $38 \%$ in 2003).

Lacking formal authority, celebrities find numerous other ways to influence policy makers. Some are simply variants on traditional diplomacy. For example, politicians are willing to meet with celebrities to raise their profile (or they may genuinely want to meet them), and in turn celebrities can use this opportunity to have access to powerful policy makers. U2 front man Bono is the undisputed master at this game (Tyrangiel 2005). Celebrities play on their own popularity and target top politicians who are fans, or have family members who are fans. Celebrities can also gain access to high-level meetings, such as the World Economic Forum in Davos, as they are thought to inject colour into otherwise bland, arcane events.

Another strategy is for celebrities to formally affiliate with established organizations, such as the UN (as 'Goodwill Ambassadors' or 'Messengers of Peace'). Former UN Secretary General Kofi Annan supported this development. His successor Ban Ki-Moon continued the policy. In 2008, he named actors George Clooney and Charlize Theron 'UN Messengers of Peace'. Legitimacy is also conferred on some celebrity activists by other institutions. Bill Gates has 
been awarded numerous honorary doctorates. Bono, and Bill and Melinda Gates were named Time's 'Persons of the Year' for 2005 (billed as 'The Good Samaritans'). Furthermore, celebrities also have the resources to create their own organizations to consolidate and 'corporatize' their activism, such as Bono's (PRODUCT) $^{\text {RED }}$ and DATA (Debt AIDS Trade Africa), or the Michael J. Fox Foundation for Parkinson's Research.

(p.262) Some use their 'home ground' - the stage on which they perform, the television show they present, award ceremonies - as an institutionalized platform for their activism. The most conspicuous example of this is Oprah Winfrey, whose endorsement allegedly boosted Barack Obama's votes in the 2008 Democratic primaries by approximately one million (Garthwaite and Moore 2008). Not only does Oprah financially support her own causes (e.g. 'The Oprah Winfrey Leadership Academy for Girls' in South Africa) and publicly endorse those of others, she also uses her show - a global institution of sorts in its own right given its durability and audience size - to provide an effective vehicle for other celebrity activists (Clooney got precious airtime to draw attention to the crisis in Darfur; actress Lucy Liu did the same for the 2005 Kashmir earthquake) and for candidate endorsement. Some celebrities choose different tactics and deliberately eschew institutional affiliations. Actor Sean Penn, for example, pursues a more radical form of activism, spending US\$56,000 to take out a fullpage advertisement in the Washington Post that berated Bush and his Iraq policy, visiting Iraq in 2003, reporting on the Iranian elections for the San Francisco Chronicle in 2005, and meeting with Venezuelan President Hugo Chavez in 2007. People like Penn and Bob Geldof receive criticism for their 'antics', but this, of course, is publicity too, and may serve to keep the public engaged with the underlying issues.

Some people are not colourful personae but have enormous financial clout. Lindblom (1977) and many others may rightly lament the disproportionate power of business in many contemporary democracies, but would they also object to the influence wielded by wealthy businessmen who choose to become do-gooders? People who own billions in personal fortune can advance political causes in a dramatic fashion. Much has been made of George Soros' role in furthering democracy in former-Soviet states. Yet eyebrows were raised when Soros then used his money and his access to media to forcefully oppose - one might say negatively endorse - George W. Bush's 2004 re-election campaign.

Which of these two tactical stances work best (or under which conditions)? We simply do not know. Hence we offer two competing propositions:

Proposition 3a: The more strongly affiliated a celebrity is with wellentrenched socio-political and cultural institutions, the more likely his/her political activities will be seen as legitimate, consequential and successful. 
Proposition 3b: The more explicitly a celebrity activist eschews being (portrayed as) aligned to well-entrenched socio-political and cultural institutions, the more likely his/her political activities will be seen as authentic, independent and successful.

Celebrity politicians: towards leadership through election

Some celebrities go beyond staying on the political sidelines and embark on fulltime political careers. Quite a few of them succeed in getting elected to (p.263) legislative or executive office. In India alone, the total number of celebrities and socialites that have become political office-holders runs into the hundreds (Mukherjee 2004: 80). In the United States, the cases of Ronald Reagan (president), Clint Eastwood (mayor), Jesse Ventura (governor), Fred Thompson (senator), and Arnold Schwarzenegger ('governator') and even astronaut John Glenn (senator) have been widely publicized, applauded, condemned, and analysed (West and Orman 2003; Indiana 2005; Drake and Higgins 2006). In the Philippines, Mexico and many other developing nations, numerous figures of the entertainment industry have likewise made it into politics. ${ }^{3}$ Electoral success is, however, by no means guaranteed. For example, global stars such as chess champion Gary Kasparov and world renowned footballer George Weah, both failed in their high-profile bids to achieve public office in Russia and Liberia. Popularity does not necessarily translate into local electability, since 'political success requires qualities beyond a famous name and celebrity background' (West 2003).

The distinctive feature of celebrity politicians is that they go all the way: they often completely abandon the world in which they gained fame - movies, music, sports, entertainment - and enter that of politics on a full-time basis. In doing so, they subject themselves to the laws of electoral politics and public officeholding, unlike celebrity activists and endorsers who tend to combine their original careers with part-time political advocacy. Once elected, celebrity politicians gain one important advantage over their counterparts: they can shrug off many of the questions about the legitimacy of their leadership that dog celebrity activists and endorsers. They are now formally representatives of the people.

\section{Getting there: the road to election}

To get there, celebrity politicians tend to capitalize on their position as popular public figures, combining it with self-conscious posturing as 'political outsiders', not 'tainted' with the awkward compromises, linguistic obfuscation, and endemic opportunism that, they claim, professional politics imposes upon its practitioners.

They are known, they are liked, and quite often they are rich - all attributes any ordinary newcomer to political campaigning craves. They are new, they are 
exciting, they are unpredictable - all attributes an incumbent politician they may run against has often long since lost.

Celebrities running for office face challenges that are different from other newcomers to electoral politics. They do not have to gain a public profile by courting publicity. Instead, they need to find a way of exploiting and at the same time subtly refashioning their existing personae to suit their new professional ambitions. It is not always easy to get the balance right. Being well-known and admired by segments of the public does not make celebrities (p.264) immune from attacks by opponents and criticism by observers. Implicitly or explicitly, celebrities taking the road into professional politics are open to charges of being ill-informed, political lightweights, dreamers, not serious, and so forth.

As is the case with celebrity advocates, running for political office may require quite considerable restyling of celebrities' public behaviour and public image to make them into credible candidates. The image makeover required is partly a function of the nature of a celebrity's pre-political profession and reputation. One could speculate that, ceteris paribus, the more meritorious the basis of a celebrity's fame, and the higher the social esteem accrued to the profession at which the celebrity excelled, the easier it is to credibly portray that celebrity as a future political leader. This proposition can predict the electoral success of high-culture celebrities such as poets (A. B. Vajpayee) and erstwhile literary 'dissidents' (Václav Havel). But it does not really account for the political ascent of 'low-culture' celebrities like Joseph Estrada (Philippine schmalz actor-turnedpresident), and Jesse Ventura (television pro wrestler-turned-state governor). Arnold Schwarzenegger would be a borderline case. His celebrity status is derived not from one but from two sources: his status as a Hollywood success (but in the typically lowbrow genres of action and family comedy), and a marriage to a Kennedy clan celebrity (hardly an asset in the Republican circles which he sought to penetrate).

And so we need to turn to other factors to help explain cases of success and failure of celebrity politicians, as well as the differential incidence of celebritiesturned-office-holders across countries. One set of factors is widely discussed in the literature: the public culture in which celebrities seek office. Clearly, media culture is a key force at work here. To what degree have politics and entertainment been merged already in the public consciousness and in the reporting practices of both political and entertainment journalists (cf. Gamson 1994; Marshall 1997: 240; Meyer 2002; Schudson 2003)? Celebrity politics presupposes an institutionalized blurring of the boundaries between politics and sports, show business and the arts, as evident from patterns of media coverage (Street 2004). West and Orman (2003) coined the term 'celebrity regime' for such a state of affairs, and argue the United States is a prime case of it. Mukharjee (2004) does the same for India. In contrast, in a media landscape where broadsheets stand firm, the state operates or controls the key television 
stations, and/or there is a living norm among journalists of all kinds that politicians' private lives are off limits, it is more difficult for celebrities to capitalize on their fame (Stanyer and Wring 2004: 5-7).

But there is arguably also an autonomous role for political culture. How much does the voting public respect and trust its current office-holders as compared to other famous people? Perhaps it is no coincidence that the case of the first ever porn star to be elected into parliament occurred in Italy, where trust in politics has been an issue for a long time. And perhaps it was no (p.265) coincidence that erstwhile 'B-movie' actor Ronald Reagan was elected president at a time of a deep crisis in American public life. Hence proposition 4: The more endemic public disaffection with 'politics as usual', the bigger the political space for even the most unlikely types of celebrities to run for office successfully.

Overlooked by almost all scholars on the subject, political structure comes into play too. Are celebrities running for president or for parliament? Are they in a single-winner (e.g. single-member constituency) or multiple-winner (e.g. party list) system, and in a majority-voting or proportional representation environment? The rules of the electoral game affect the scope for celebrity power via the ballot box. In countries with multiple-winner constituencies and proportional representation, and a robust party system, celebrities can often only gain office through an existing political party. To be pre-selected, they must be 'team players' and abide by the requirements of party discipline imposed by its leaders. Once elected they may end up in opposition, or on the back benches along with the party's other novice parliamentarians.

In many polities therefore, celebrities cannot run their own (electoral) show. This may put off many of them who have become used to doing precisely that. So we are more likely to see celebrity politicians seeking and achieving office in countries with single-member constituencies (where the ultimate battles are between individual candidates), majority voting (where they are not so dependent upon arcane vote aggregation rules) and/or relatively weak political parties (which are more prone to co-opt political outsiders). Celebrities - with high profiles, but quite often big egos to match them - might not be prepared to submit to a political apprenticeship before they can exercise a significant leadership role. Used to the limelight, and having that limelight as their main asset in politics, they may be ill-prepared for instructions from above to shun it for the greater good of the party. Party hierarchy, party programmes, and party discipline: not a good habitat for the celebrity politician. Hence proposition 5: The more aspirants to political office are dependent for their election on entrenched catch-all political parties, the less widespread the incidence of celebrities running for office. 
The United Kingdom provides a good example of this. Even though it is a single member, majority-voting system, its party organizations are well entrenched and for the most part deeply conservative in their recruitment practices. Other than Glenda Jackson (Labour MP since 1992) and Sebastian Coe (Conservative MP 1992-7, currently in the House of Lords) almost no celebrity from the world of entertainment, the arts, and sports has successfully attempted a VIP-entry into politics. This applies in even stronger degree to the smaller West-European countries, where multi-member constituencies and proportional representation make celebrities entirely dependent on party hierarchies for an electable spot on the party list. In the Netherlands, for example, the number of celebrity politicians in parliament has always been zero or close to it; at the same time, since members of the government (p.266) can be recruited from outside politics, (minor) celebrity academics and business leaders have sometimes entered politics in this way, but they tend to disappear quickly when their terms as ministers are up. In contrast, in Finland, where there is open-list, preferential voting, the number of celebrities in representative institutions is comparatively high (Hautamäki and Kaarto 2006).

There are two ways for celebrities to overcome the barriers created by party gatekeeping practices. One is to 'take over' an existing party and enter it right at the top, as Schwarzenegger to some extent did in the Californian Republican Party. The celebrity can then sidestep the conservers in the party machine, and make the party hierarchy work for him (or reform it to consolidate his leadership). When are they most likely to be able to pull this off? Perhaps the most evident situation is when a party is suffering electorally. As a matter of survival, its power brokers will start to look around for potential saviours to pull it out of oblivion. In these circumstances, criteria such as ideological purity, appropriate gravitas and grass-roots experience quickly lose relevance. Outsiders with money or fame (but preferably both) are well placed to pose as saviours and be believed.

The other option for office-seeking celebrities is to simply bypass existing parties and form one's own. The personalist party has been around for a long time in, for example, Latin America (Vargas in Brazil, Peron in Argentina, see Lewis 1973), but it is a relatively new and rare phenomenon in many Western European countries, whose PR-systems offer potentially good prospects for it. The sagas that do exist are revealing though. Sweden had its New Democracy party founded by and built around two celebrities (an aristocrat-industrialist and a record company owner) in the early 1990s. The Netherlands saw the rise and fall of the List-Pim Fortuyn in the early 2000s. It was formed by the eponymous public intellectual cum extravagantly gay socialite Pim Fortuyn, after he repeatedly failed to gain a prominent position in virtually all of the main existing political parties. Both parties took radical right-wing positions on issues like immigration and Islam, both were highly successful at first in capitalizing upon the charisma of their celebrity founders. Both, however, proved short-lived. New 
Democracy's two figureheads had a very intense and very public falling out, and the party disintegrated after just one term in parliament (one of the founding duos ironically went on to develop a successful TV show called Fame Factory). Fortuyn was assassinated a few days before he contested his first election; the party nevertheless received almost 20 per cent of the seats in the 2002 parliament and found itself a member of the new coalition government. An intense and widely reported power struggle between Fortuyn's hitherto anonymous lieutenants helped decimate its popular support within four years. Although often meteoric in their rise, charisma-based personalist parties are latently unstable, and tend not to last, although (p.267) exceptions (Peronism in Argentina and Gaullism in France; Berlusconi's Forza Italia) do exist.

In whichever form celebrities choose to make the run to office, they all face the same key dilemma: how to position their past life (the extra-political source of their celebrity) in the frame of their new, political life. Before entering politics the celebrity may have lived in ways that can be a source of political embarrassment. Shadows from their past have a way of catching up with celebrities in general, and even more so with those who now have to get elected by large numbers of ordinary, law-abiding heartland citizens. Pictures and stories of sexual exploits, drug habits, 'bad' company, personal profligacy, past partners, and neglected children may arise. Such 'revelations' (often old stories known among insiders but now dramatized through fresh evidence or ruthless journalistic framing) can turn the celebrity's past life from a great asset into a potential liability virtually overnight. Did Arnold take drugs on his road to become bodybuilding champion? And was he 'rough' in sexual encounters? What casualties did he make on his road to bodybuilding and acting glory? Were Arnie's parents Nazis? And what exactly were young Arnold's political beliefs? In fact, celebrity politicians who first were celebrity activists may be haunted by the very purity and radicalism of their early political stances. Midnight Oil singer-turned-Australian Labor MP and then Environment minister Peter Garrett is a case in point (Daily Telegraph 2007; Sydney Morning Herald 2007).

Schwarzenegger overcame all that with apparent ease. Perhaps he simply has more political savvy than Garrett. Perhaps he has better spin doctors to advise him how to cope with these shadows of the past. The challenge for celebrity politicians is to draw political capital from the idiosyncrasy credit (Hollander 1978) they enjoy because of their star status, and avoid being dragged down by it. Covering up or lying about aspects of their past that may reduce their electability, as ambitious political newcomers sometimes do, is hardly an option for celebrity-newcomers: the details of their lives are a matter of public knowledge. Their job is to frame the story of their past life, so as to make it work for, and not against their current political aspirations. Some resolve this potential tension by perfectly matching a rather outrageous pre-political life with an equally outrageous political persona, like Italian porn star-turnedparliamentarian Cicciolina, who among other things offered to have sex with 
Saddam Hussein in exchange for peace. This will only work in a parliamentary system where niche popularity (local or sectional) is enough to ensure election; this strategy would be near impossible for those running for executive office. Overall, proposition 6 may best capture the dynamics: The larger the discrepancy between a celebrity politician's past and current life styles, espoused political values and policy preferences, the greater the likelihood that this celebrity will suffer credibility damage from selective media exposure of his past.

(p.268) Being there: celebrity leaders in office

To achieve high political office is one thing; to hold on to it over time and to utilize it to display effective leadership are quite different challenges. There is no systematic research available that compares the length of tenure of celebrity politicians to the average in their respective jurisdictions, but our hypothesis is that particularly in established democracies, celebrities on average do not last very long. None of the previous Dutch, Swedish, and Italian examples lasted longer than five years, although counterexamples (Glenda Jackson, Silvio Berlusconi among them) are not difficult to find either. One could argue that for the reasons set out above, celebrity politicians in parliamentary systems with strong cadre parties are likely to find their time in politics frustrating rather than uplifting. They may fare better in presidential systems, where legislators can build up much more of an individual profile; and even better when elected to executive office, where they can - within limits - actually call the shots. Hence the logic of proposition 7: In established democracies, the average tenure of celebrity politicians is shorter than that of professional ones; and it is shorter in presidential than in parliamentary systems.

The art of executive leadership is markedly different from that of campaigning or legislating, although perhaps in a fully developed 'celebrity regime' that distinction becomes increasingly obsolete (the 'permanent campaign' syndrome). Are celebrities good at governing? Again, systematic research is lacking and the total number of cases in the Western world is still too limited, so no empirically founded generalizations are possible. Talking about the US context, West (2003) argues that the record of celebrity leadership in government is mixed: "To win office, celebrities often assemble unconventional coalitions that transcend normal party alignments. Unlike established politicians who most appeal to conventional political constituencies, celebrities can build coalitions that are more broad-based...[T] his same quality harms them in the governing process. The presence of broad voter support often is based on an allegiance that is not very deep'. Likewise, 'the very qualities (independence and unconventionality) that voters find appealing often alienate the media and legislators. When these individuals start complaining, voters sometimes see the celebrity as an amateur and a novice who is not up to the governing task. If that perception becomes widespread, it is hard for celebrity politicians to govern very effectively'. 
Still, Ronald Reagan consistently pops up in the upper ranks of almost every 'presidential greatness' poll taken since the end of his presidency. In office, he displayed a remarkable capacity to overcome gaffes, setbacks, and outright fiascos (such as the Iran-Contra affair) and retain personal popularity (see Schwartz 1990). A celebrity war hero-turned-president, Dwight Eisenhower is up there as well, ever since historians discovered that behind the veneer of the disengaged, golf-playing president lies a man whose 'hidden-hand' (p.269) leadership style was far more pervasive and effective than generally assumed during his time in office (Greenstein 1982). Both these celebrity presidents achieved relatively high popularity scores whilst in office; both had no problems getting re-elected. But their enduring esteem as effective policy-makers owed perhaps less to their celebrity status as to relevant experience of governing (Eisenhower as supreme allied commander during the Second World War and Reagan as governor of California). At the state level, Jesse Ventura's initially skyhigh popularity did not last for more than a year or two, and he retired as governor of Minnesota after one term. Arnold Schwarzenegger on the other hand proved comfortable with leading America's most populous state, was reelected in 2006, and appears well-entrenched at the helm of Californian politics. In all, although the record is mixed and broad cross-national variation is as yet lacking, we might offer a final proposition 8: Celebrity politicians are more likely to exercise effective leadership in executive rather than legislative roles.

\section{Politician-celebrities: leader self-dramatization and victimization}

The fourth type of celebrity politics is fundamentally different from the other three. In its case, the direction of the flow between the two spheres is reversed: now we are looking at established politicians who enter the sphere of celebrity by their own intent and design (in Table 14.1: P-C1s) or by somehow appealing to the cohort of celebrity (rather than just political) journalists and commentators, unwittingly becoming subjected to celebrity-style media coverage, commentary and gossip, and thus acquiring a new level of public visibility and/or undergoing a significant 'reframing' of their 'images' as professional public leaders - for good or for bad (in Table 14.1: P-C2s).

The P-C1s are a manifestation of traditional institutional politics coming to terms with the media age and consumer culture. So much has been written about this already that we can be brief here (Graber, McQuail, and Norris 1998; Perloff 1998; Meyer 2002). Personalizing authority through projecting 'the person behind the leader' in every possible media outlet reflects the transformation in political communication in an age where policy struggles and electoral fates are no longer resolved in the classic corporatist and parliamentary arenas but in increasingly open, fluid, deliberative, symbolic ones. In those arenas 'politics as usual' is not necessarily the main game (and perhaps not more than a sideshow). Political actors - executives, legislators, bureaucrats, advocates, stakeholders have had to adapt to several such transformations over time, as radio, television, and the internet came along, greatly affecting the media landscape and patterns 
of mass communication. All of them have worked in the same direction: towards an increasing emphasis on the personal (p.270) and the dramatic, and towards an increasing convergence between the logics of political leadership and business marketing. Democratic politics, like marketing, has always been about persuasion; but these days the techniques used in persuading publics of the merits of certain ideas, parties, and people have become almost indistinguishable from those used in 'branding' firms, products, and indeed 'stars' (Needham 2005).

Of all the (sub)types of celebrity politics discerned in this chapter, the P-C2s are the only ones who have celebrity happening to them rather than either seeking and/or exploiting it. P-C2s are people whose life outside politics inadvertently triggers attention well beyond the niche market of political journalism. Normally, this would be behaviour deemed to be unsuitable, outrageous, and in short 'scandalous': hard drinking or drug use, conspicuous partying, association with dubious characters, sexual adventurism, and loss of composure in public. Although this results in them and their lives getting covered by the celebrity stratum of journalism, they are first and foremost notorieties instead of celebrities. And in politics, notoriety often comes at a high price: relentless scrutiny, decline of political capital, legal battles and retribution, and not seldom loss of office (Markovits and Silverstein 1988; Tiffen 1999; Thompson 2000). In a sense, P-C2s end up as the casualties of contemporary media democracy: prior to the widespread blurring of political and entertainment journalism, their private vices would not have turned into public issues at the same speed, scale, and intensity.

The epitome of the leader who will be remembered as much for his scandals as for his record, Bill Clinton's 'colourful' persona and private life turned him into a celebrity, a notoriety even, and ended up crippling his presidency, although his personal approval ratings remained remarkably high throughout the ordeal. Despised by many yet liked by even more, he could continue to function as a public leader in some arenas, but was forced throughout his second term to fight an energy-sapping battle for political survival.

Celebrity, leadership, and democratic politics: normative reflections Having mapped out the various forms of celebrity politics, it is time to reflect on their relevance for democratic leadership. Two questions are in order. To what extent and how do these manifestations of celebrity politics amount to distinctive forms of leadership? And in as far as they do, do they amount to a form of leadership dispersal that strengthens or detracts from the democratic authenticity of politics?

The answer to the first question, not surprisingly, is 'it depends'. For one, we should not confuse either influence or office-holding with leadership. Influence and power imply causing specific 'targets' to think and act in certain (p.271) 
ways; leadership is about acquiring, maintaining, and affecting followers.

Arguably, celebrity activists are sometimes influential in swaying legislators' and executives' attention and opinion on certain issues, but many of them do not seek, service, respond to or direct 'followers'. Their political activism is at best an expression of their individual beliefs, values, and aspirations, at worst a form of self-promotion masterminded by others. Few of them explicitly claim to represent a broader constituency - perhaps intuitively knowing how problematic such a claim turns out to be (Saward 2006, see further below). Likewise, the mere fact that celebrities may have a comparative advantage in attaining legislative or executive office does not necessarily mean that they effectively use these offices to exercise significant leadership in terms of public, policy, and political impact. Some remain back-benchers; some executive celebrities fail or refuse - Jesse Ventura is a case in point here - to sufficiently adjust to the rules of the game of institutional politics, or fail to transcend those rules once in office.

So any assessment of celebrity politics in terms of leadership has to be a cautious and contingent one. With that in mind, let us revisit the various archetypes of celebrity politics discussed here, and weigh their significance in terms of four logics of dispersed leadership (checks and balances, fragmentation, and emancipation being the most important one; delegation is not at stake here); (see further chapter 16).

\section{Celebrity endorsement and activism revisited}

Celebrity endorsement and activism can and do frequently serve to harness and even reinvigorate democratic politics. They may be actively aimed at stimulating public involvement and demanding greater transparency from policy-makers. They force politicians and bureaucrats to take into account the demands and opinions of a wider societal - indeed sometimes global - demographic. On the downside, it can exacerbate the pathology of politics as a popularity contest, which greatly disfavours social problems and groups that celebrities choose not to pay attention to or shy away from (unpopular, controversial, or unglamorous causes). In-depth analysis and careful deliberation may give way to star power, clever marketing, rock concerts, and cleverly made but ultimately shallow docupics and blogs.

On the front stage of democratic politics, celebrity activism does, however, offer an unorthodox but potentially effective way of breaking the hold of established elites on political agendas and public discourse about policy. Celebrities have a unique capacity to reach out to and mobilize otherwise apathetic publics. They sometimes manage to give powerful voices to the disenfranchised in society and at the world stage. Where legislatures and other institutional watchdogs may be fully co-opted by executive dominance, celebrity-led initiatives can help 'keep the bastards honest'. 
(p.272) Celebrity endorsement and activism has the potential to contribute to the intelligence and deliberative quality of democracy by educating segments of society about public issues they would otherwise remain ignorant about (George Soros's extensive programmes in Central and Eastern Europe come to mind). At the same time, celebrity-focused publicity tends to gloss over crucial facts and complexities. And the strong amplification that celebrity voices receive in the public discourse may crowd out the perspectives provided by other, less famous interlocutors. Top celebrity activist Bono, for example, is advised on economic policy by Jeffrey Sachs - the man whose ardent belief in 'shock therapy' has brought various 'new democracies' economic chaos and political turmoil, and who has since revised his theories (see Klein 2007). Policies on debt relief masterminded by Sachs and amplified by Bono are the ones that get beamed to the public through mega-spectacles such as the Live 8 concerts. Other theories and policy formulas hardly compete on a level-playing field.

There is also considerable scope for scepticism. As noted, the fact that celebrity activists and endorsers are essentially leaders without followers raises thorny issues of representation. Who or what can the Jolie's and Bono's of this world legitimately claim to represent? Their fame is as boundless as the scope of their political causes, but it would be a stretch to argue their leadership is embedded in some form of cosmopolitan democracy (Held 1995; Saward 2006). In contrast, celebrity politicians seek to obtain institutional (party preselection, electoral mandate) backing for their public leadership aspirations, albeit at the price of eventually - having to become more of an 'ordinary politician' in the process.

Other critics question whether celebrities are really usefully understood as (political) actors in their own right. Perhaps they should be seen more as cultural emblems or as not more than products of an entertainment-industrial complex that creates, sustains, utilizes, and discards them when economic logic so dictates. Turner et al. (2000: 9), for example, follow Alberoni's analysis of 'stars' to argue that while they enjoy some of the privileges of an elite, celebrities are an institutionally 'powerless elite' - objects of interest over which they have no control.

Some have gone much further in their critique, not just of celebrity activists but of the entire entertainment culture and celebrity politics of which they are but one manifestation. Public intellectuals such as Daniel Boorstin and Neil Postman dismiss all of these as a despicable trend that epitomizes the banal and the mindless in public life, empowering image over substance and producing pseudo-charismatic leadership (cf. Weiskel 2005).

\section{Celebrity politicians revisited}

Whether we like it or not, there can be little doubt that celebrity entails potentially significant political capital for people seeking to exercise public (p. 273) leadership. This is particularly so for celebrities seeking to attain high 
public office. Two long-time students of celebrity politics note: 'Even though Americans tend not to trust politicians, they have great respect for and confidence in celebrities who enter the world of politics...These individuals have a fame that transcends public service and a reputation for personal integrity. This allows them to succeed politically in ways that are unavailable to more conventional kinds of politicos' (West and Orman 2003). It makes celebrities particularly well-suited to play the Weberian game of plebiscitarian politics, which many have argued has regained prominence as established patterns of electoral democracy - voter alignment, voter participation, party stability; party competition - weaken. Silvio Berlusconi is a classic case in point.

But the Berlusconi example in many ways also feeds the fire of critics who point out that celebrity politics thrives by virtue of the public behaving as admiring fans rather than discriminating citizens. The undiluted admiration that comes with fandom may in some cases develop into charismatic forms of leaderfollower relations (cf. Marshall 1997: 20-6; Hughes-Freeland 2007) which, as Weber suggested, is not necessarily an authority pattern that comfortably sits within institutional democratic politics. There is even plenty of evidence to suggest that celebrity frequently gives rise to psycho-pathological phenomena among both the famous and their fans (Giles 2000; Ferris 2007). Obviously, being widely known and admired can be a great asset for a leader who wants to get elected and get things done. But: What if the causes pursued by charismatic celebrity-leaders are not so noble? Who or what checks the power of celebrity leadership?

We are not to worry, according to economist Tyler Cowen. In What Price Fame (2000: 170) he has argued that 'the burdens of fame provide a new means of limiting political leaders, a means overlooked by Hobbes and subsequent classical liberal commentators. The separation of fame and merit is part of the price we pay for modern democracy, which relies heavily on media to monitor our leaders'. Insofar as they seek to utilize their own 'star power' or exploit that of others, political leaders of both the conventional and celebrity kind will have to submit to relentless public scrutiny of their lives that goes far beyond the accountability regime of parliamentary scrutiny and political journalism. Far from empowering the famous to lead without restraint, celebrity instead provides a relatively fickle and fleeting form of leadership capital, Cowen argues. This is because of the media-entertainment complex's insatiable appetite for not only building up certain people as celebrities but also bringing them down and replacing them by other, fresher faces. Albeit unwittingly, it provides a strong mechanism for cutting rascals down to size and throwing them out when their 'sell-by' date has elapsed. Perhaps democrats should not condemn celebrity leadership out of hand? 


\section{(p.274) Politician-celebrities revisited}

Cowan's 'checks and balances' interpretation of celebrity politics is perhaps best tested by examining the fate of politician-celebrities. Are they being kept in check by the pressure of celebrityhood, or do they succeed in exploiting celebrity to maximize personal power? If the latter holds, celebrity politics takes us about as far away from leadership dispersal as one could get. The fates of politicians acquiring celebrity features are, of course, mixed. Cowan got it at least half right. Blair's mastership of 'spin' was arguably a big asset to him in his early years, but when spin itself became part of the Blair story it turned against him and constrained him. And French president Sarkozy embraced celebrity in his courtship of Carla Bruni, only to find significant backlash against him among the French public, which apparently valued the dignity of the office more than the joy of reading daily gossip about the exploits of its current holder. But after marrying Bruni and resorting to a more classic presidential style, he began to appear more Kennedy-esque again. The incidence of personal gossip and the air of scandal that are part and parcel of celebrity life can therefore be seen as a taming force on political leaders in the manner suggested by Cowan, particularly for P-C2s.

However, there are sharply contrasting views on the other side of the politiciancelebrity coin, the P-C1s. An optimistic assessment of it emphasizes that it is all about 'professionalization' of the persuasive tool kit that democratic politicians need to have in the contemporary age. If this requires that they themselves become a pivotal part of the story, so be it. Hence, we acknowledge the skill of leaders such as Tony Blair, Gerhard Schröder, and Barack Obama (see De Beus, this volume). P-C1 leaders surround themselves with political marketers and communication advisers, and project non-traditional political personae, reach out to all corners of the media and Internet spectrum, and do not hesitate to highlight their personal histories, idiosyncrasies, and families. Their objective: not just to get (re-)elected but to become a 'strong brand', one that receives the benefit of the doubt when it launches a new product line (proposes a new policy) or one that endures through tough times (fiasco and scandal).

The pessimistic accounts of $\mathrm{P}-\mathrm{C} 1 \mathrm{~s}$ come in various shapes. One stresses that this so-called professionalization of political communications and personalization of public leadership is really nothing but a desperate, and in the end ineffectual, move by political parties and public institutions to stay relevant in a society that governs itself increasingly without them. Leadership dispersal through the rise of governance and 'netizens' is the big trend; centralizing the paraphernalia of state power around executive celebrity leaders is essentially a defensive and increasingly trivial move (Frissen 1999; Bang 2003; Bevir and Rhodes 2006). Another stresses that the rise of the media-savvy politician-celebrity amounts to a 'dumbing down' of public deliberation. Politics comes (p.275) to many today in the form of hollow talk about 'pseudo events', for instance the lives and antics of leaders instead of substantive discussion about issues, ideas, and policies 
(Boorstin 1961). A third suggests that the rise of P-C1s in fact constitutes a significant yet sinister development: in a world saturated with political 'spin' and 'soap' the active citizen is deliberately reduced to a passive consumer-spectator, prone to be efficiently manipulated by the politics of distraction and misinformation (Edelman 2001).

\section{Concluding observations}

We cannot settle these debates in this chapter. There is simply too much to be learned about the causes, incidence, forms, and effects of celebrity politics and leadership across democratic polities. The eight propositions offered here hopefully provide a viable starting point for the kind of systematic empirical analysis that the literature is so sorely lacking (Duvall 2007), which should also include the two forms of celebrity leadership not covered here (cf. Table 14.1). We need to know more about the similarities and differences between various national systems of political celebrity production, as well as the degree to which transnational celebrity power affects national political processes. Let us not forget that even in this day and age, completely and in fact deliberately 'traditional' politicians can and do remain very effective in getting elected and exercising leadership, despite the pressures of the media-cultural complex to 'personalize' their persona (Van Zoonen 2006). We need to acquire a more finegrained picture of celebrity politics, and compare different types of celebrities, different celebrity leadership tactics, and different electoral and executive settings.

Only when we have a firmer empirical footing can we fully address the normative question raised by Cowen and others: is the emergence of a celebrity regime at the intersection of entertainment and politics a bad or a good thing for democracy? If we deplore the power of money in election campaigns and seek to curtail monetary donations to parties and candidates, how do we view the increasing number and scope of political endorsements by celebrities? Which forms and extent of celebrity activism do we regard as democratically desirable, and which not? And when do the celebrity antics of incumbent politicians (such as Bill Clinton or Nicolas Sarkozy) begin to erode the institutional legitimacy of the offices they hold?

Bibliography

Bibliography references:

Australian Associated Press Pty Limited, 'Garrett Denies Selling Out Beliefs', Daily Telegraph, 1 April 2007, available at: 〈http://www.news.com.au/ dailytelegraph>.

'Garrett Pathetic Over Pulp Mill: Howard', Sydney Morning Herald, 9

October 2007, available at: 〈http://www.smh.com.au/news〉. 
Bang, H., (ed.), Governance as Social and Political Communication (Manchester: Manchester University Press, 2003).

Bevir, M. and Rhodes, R. A. W., 'Prime Ministers, Presidentialization and Westminster Smokescreens', Political Studies, 54/4 (2006), 671-90.

(p.277) Boorstin, D. J., The Image, or, What Happened to the American Dream (London: Weidenfeld and Nicholson, 1961).

Braudy, L., The Frenzy of Renown: Fame and its History (Oxford: Oxford University Press, 1986).

Cooper, A. F., Celebrity Diplomacy (Boulder: Paradigm Publishers, 2008).

Cowen, T., What Price Fame (Cambridge, Mass.: Harvard University Press, 2000).

Drake, P. and Higgins, M., ' "I'm a Celebrity, Get Me into Politics”: The Political Celebrity and the Celebrity Politician', in S. Holmes and S. Redmond (eds.), Framing Celebrity (London: Routledge, 2006), 87-100.

Duvall, S-S, 'A Star is Made: News Coverage of Celebrity Politics in the 2000 and 2004 US Presidential Elections', Paper presented at the Political Studies Association Conference, 2007.

Edelman, M., The Politics of Misinformation (Chicago: Chicago University Press, 2001).

Ferris, K. O., 'The Sociology of Celebrity', Sociological Compass, 1/1 (2007), 37184.

Frissen, P., Politics, Governance and Technology (Cheltenham: Edward Elgar, 1999).

Gamson, J., Claims to Fame: Celebrity in Contemporary America (Berkeley: University of California Press, 1994).

Garthwaite, C., and Moore, T., 'The Role of Celebrity Endorsements in Politics: Oprah, Obama, and the 2008 Democratic Primary', September 2008, available at: http://www.econ.umd.edu/ garthwaite/

celebrityendorsements_garthwaitemoore.pdf

Giles, D., Illusions of Immortality: A Psychology of Fame and Celebrity (New York: Macmillan, 2000).

Graber, D., McQuail, D., and Norris, P. (eds.), The Politics of News: The News of Politics (Washington: CQ Press, 1998) 
Greenstein, F. I., The Hidden-Hand Presidency: Eisenhower as Leader (New York: Basic Books, 1982).

Hartley, J., Popular Reality: Journalism, Modernity, Popular Culture (London: Edward Arnold, 1996).

Hautamäki, J. and Kaarto, H., 'Politics Goes Entertainment,' Helsingin Sanomat, 3 December 2006, available at: 〈http://www.hs.fi/english/article/ Politics+goes+entertainment/1135223472392).

Held, D., Democracy and the Global Order: From the Modern State to Cosmopolitan Governance (Cambridge: Polity Press, 1995).

Hollander, E. E., Leadership Dynamics: A Practical Guide to Effective Relationships (New York: Free Press/Macmillan, 1978).

Hughes-Freeland, F., 'Charisma and Celebrity in Indonesian Politics', Anthropological Theory, 7/2 (2007), 177-200.

Indiana, G., Schwarzenegger Syndrome: Politics and Celebrity in the Age of Contempt (New York: New Press, 2005).

Klein, N., The Shock Doctrine: The Rise of Disaster Capitalism (Victoria: Allen Lane, 2007).

Lewis, P. H., 'The Durability of Personalist Followings: The Vargas and Peronist Case', Polity, 5/3 (1973), 401-14.

Lindblom, C. E., Politics and Markets: The World's Political-Economic Systems (New York: Basic Books, 1977).

Marshall, P. D., Celebrity and Power: Fame in Contemporary Culture (Minneapolis, Minn.: University of Minnesota Press, 1997).

(p.278) Markovits, A. S. and Silverstein, M. (eds.), The Politics of Scandal: Power and Process in Liberal Democracies (New York: Holmes and Meier, 1988). Meyer, T., Media Democracy: How the Media Colonize Politics (Cambridge: Polity Press, 2002).

Monaco, J., Celebrity: The Media as Image Makers (New York: Doubleday, 1978).

Mukherjee, J., 'Celebrity, Media and Politics: An Indian Perspective', Parliamentary Affairs, 57/1 (2004), 80-92.

Needham, C., 'Brand Leaders: Clinton, Blair and the Limitations of the Permanent Campaign', Political Studies, 53/2 (2005), 343-61. 
Perloff, M. R., Political Communication: Politics, Press and Public in America (Mahwah, New Jersey: Erlbaum, 1998).

Pringle, H., Celebrity Sells (London: Wiley, 2004).

Rein, I., Kottler, P., and Stoller, M., High Visibility (New York: Dodd, Mead and Company, 1987).

Rojek, C., Celebrity (London: Reaktion Books, 2001).

Saward, M., 'The Representative Claim', Contemporary Political Theory, 5/3 (2006), 297-318.

Schudson, M., The Sociology of News (New York: Norton, 2003).

Schwartz, B., 'Ronald Reagan Misremembered', in D. Middleton and D. Edwards (eds.), Collective Remembering: A Social Psychological Approach (London: Sage, 1990), 108-19.

Shapiro, I. and Hacker-Cordon, C. (eds.), Democracy's Edges (Cambridge: Cambridge University Press, 1999).

Stanyer, J. and Wring, D., 'Public Images, Private Lives: An Introduction', Parliamentary Affairs, 57/1 (2004), 1-8.

Street, J., 'Celebrity Politicians: Popular Culture and Political Representation', British Journal of Politics and International Relations, 6/4 (2004), 435-52.

- - 'Politics Lost, Politics Transformed, Politics Colonised? Theories of the Impact of Mass Media', Political Studies Review, 3/1 (2005), 17-33.

Tiffen, R., Scandals: Media, Politics and Corruption in Contemporary Australia (Sydney: University of NSW Press, 1999).

Thompson, J. B., Political Scandal: Power and Visibility in the Media Age (Cambridge: Polity, 2000).

Turner, G., Bonner, F., and Marshall, P. D., Fame Games: The Production of Celebrity in Australia (Cambridge: Cambridge University Press, 2000).

—- Understanding Celebrity (London: Sage, 2004).

Travers, P., 'George Clooney', Rolling Stone, 673 January (2008), 61-3.

Tyrangiel, J., 'The Constant Charmer', Time, 166/26 (2005), 46-62.

Van Zoonen, L., 'The Personal, the Political and the Popular: A Women's Guide to Celebrity Politics', European Journal of Cultural Studies, 9/3 (2006), 287-301. 
Weiskel, T., 'From Sidekick to Sideshow: Celebrity, Entertainment, and the Politics of Distraction. Why Americans are "Sleepwalking Towards the End of the Earth" ', American Behavioral Scientists, 49/3 (2005), 393-403.

West, D., 'Arnold Schwarzenegger and Celebrity Politics', InsidePolitics.org, 6 October 2003, available at: 〈http://insidepolitics.org/heard/westreport903.html).

_- and Orman, J., Celebrity Politics (Englewood Cliffs: Prentice Hall, 2003).

\section{Notes:}

(1.) We would like to thank Rod Rhodes, Harald Wydra, Bob Goodin, Michael Schudson, John Kane, the other participants at the authors' workshop in Utrecht, and participants at this paper's presentation at the Political Science Program Seminar at the Research School of Social Sciences of ANU for helpful comments and suggestions.

(2.) The impact of a celebrity's activism can also be dependent on what happens in their 'regular' careers and their private lives. If they are out of the spotlight professionally they may lose their power to gain interest for a cause. If they become embroiled in personal scandals or controversies this can tarnish their cause. But, paradoxically, the latter may also benefit it. Tabloid coverage of their personal travails does raise the profile of celebrities, and this in turn consolidates their main political resource - their attention-getting potential. It depends on the kind of publicity involved: the odd marital breakdown will probably not hurt a celebrity's 'market value'; personal tragedies in fact enhance it and may give celebrities personal credibility in specific areas (former US first lady Betty Ford and stricken actors Christopher Reeve and Michael J. Fox are prime examples of this). But when publicity is consistently negative, a celebrity's standing with the public suffers, and so too the potential for effective activism. The spectacular disintegration of Michael Jackson's or O. J. Simpson's public persona surrounding their alleged involvement in major crimes made them unsuitable to promote any product, let alone pursue good causes. Although under some circumstances celebrities that are mainly notorieties have the potential to be political marketing assets (the 'reformed criminal', the 'former junkie'), originally meritorious celebrities that become notorieties because of personal aberrations (or worse) are clearly non-starters in the world of celebrity activism.

(3.) Other countries, particularly those of Western Europe as well as Australia and New Zealand seem remarkably impervious to such celebrity inroads into electoral politics - although the Australian Labour Party successfully launched former rock star Peter Garrett (of Midnight Oil fame), and then high-profile television journalist Maxine McKew in the national election of 2007. The crossnational differences between high and low incidences of celebrity politicians are an interesting phenomenon worth studying in its own right, particularly since 
standard explanations of the phenomenon tend to emphasize universal trends in the media technology, ownership, and culture as the chief causes. Obviously, these cannot account for such differences, which suggests that elements of political structure (e.g. electoral systems and party systems) and political culture (e.g. attitudes towards 'traditional' politics and politicians) should be factored into the explanation.

\section{Access brought to you by:}

